\title{
REFERENCES
}

1. Makarinska A.V. State of production and provision of Ukrainian population products of livestock / A.V. Makarinska // Cereal products and feed. - 2010. - No. 2. - with. 37-39

2. Nechitaylo Y.Y. Development of technology for the production of feed additives from by-products of hydrobionts processing [Electronic resource] / Y.Y. Nechitaylo // Access mode: http://extrutec.ck.ua/lectures/2.html

3. Strategy of feeding pigs without the use of animal feed [Electronic resource] - Access mode: https://soft-agro.com/svini/strategiya-kormleniyasvinej-bez-ispolzovaniya-kormov-zhivotnogo-proisxozhdeniya.html

4. Ponomarev V.V. Protein concentrate and the method of its production [Electron resource] / V.V. Ponomarev, T. M. Bikbov - Access mode: https://patents.google.com/patent/WO2010123396A1/ru

5. Concentrate of soy protein (fodder) [Electronic resource] - Access mode: http://www.sodrugestvo.ru/our_business/global_trade/own_production/spc/

6. Protein concentrates [Electronic resource] - Access mode: http:/lfood-chem.ru/lektsii-po-khimii-belkov/belkovye-kontsentratyteksturirovannye-belkovye-produkty

7. Protein of vegetable origin [Electronic resource] - Access mode: https://agrosmak.ua/belok-rastitelnogo-proischogdenia/

8. Jackson M. Improving soya utilization in monogastrics: bread-soya diets with B-mannanase [Text] / M. Jackson // Feed international. - 2001. V.22 - No. 12. - P. 22-26.

9. $\quad$ Turin E. Soya in feeding birds / E. Turin // Livestock of Ukraine. - 2008. - No. 2. - P. 31-32.

10. Bortnikov S. Efficiency of using full-fat extruded soybeans [Text] /S. Bortnikov // Combined feed. - 2005. - №1. - P. 51-52.

11. Specialty Protein Concentrate (Hamlet Protein) Denmark [Electronic resource] - Access mode: : http://www.altua.com/ru/catalog/raw/protein-components/specialized-protein-concentrate.html

12. Podobed L.I. Hamlet Protein [Electronic resource] / L.I. Podobed // Access mode: http://podobed.org/gamlet_protein.html

13. What is a part of the predsters for pigs [Electronic resource] - Access mode: https://soft-agro.com/svini/sostavlyayushhie-prestarterov-dlyaporosyat.html

14. Ibatulin II Feeding farm animals / I.I. Ibatulin, D.O. Melnichuk, G.O. Bogdanov, etc.: a textbook. - Vinnitsa: New Book, 2007. - 616 p. Надійила 08.06.2018. До друку 26.06.2018. Рецензія 14.06.2018

T.V. SAKHNO, chem. sci. dr., professor, P.V. PISARENKO, agr. sci. dr., professor,

I.V. KOROTKOVA, PhD in Chemistry, Poltava State Agrarian Academy,

O. M. OMELIAN, PhD in Phis.-math., Poltava National Technical University Yu. Kondratyuk',

N. N. BARASHKOV, chem. sci. dr., professor, Micro-Tracers Inc., San-Francisco, USA

\section{THE APPLICATION OF STATISTICAL METHODS OF QUALITY MANAGEMENT BY GMP+ STANDARDS USING FERROMAGNETIC MICROTRACERS}

\begin{abstract}
The GMP +FSA Feed Certification scheme is considered and analyzed which was developed in 1992 by the Dutch feed industry in response to various incidents involving contamination in feed materials. Currently it is an international scheme that is managed by GMP+ International in collaboration with stakeholders from numerous European countries. One of the most important and responsible steps in the feed production is mixing - creating a completely homogeneous mixture. In this paper, a statistical quality assessment of mixing of multicomponent feeds using the distribution of added particles - microtracers was performed. The testing procedure of the homogeneity of feeds and premixes using microtracers is presented in the Standard GMP+ BA2 "Control of residues". The ferromagnetic variety of microtracers manufactured by American Company Micro-Tracers, Inc (San Francisco, California) are elementary iron particles or particles of stainless steel which are coated with a FD\&C dye of different colors. The most common microtracers are Microtracer F that consists near 25000 of iron particles with a size distribution of 150 - $300 \mu$ m. These microtracers are used in the feed industry to ensure the quality of mixing feeds for animals and poultry during the last $20-30$ years. The additional areas of use of microtracers include the marking of vitamins, mineral additive or medicament which introduced into premixes, which allows to mark the presence of the premix in the finished feeds. In quantitative analysis, Microtracers ${ }^{T M}$ can be used not only to document efficacy of mixing, but also to assess the adequacy of batch to batch "cleanout" of mixers and other feed manufacturing equipment.

In the present article the analytical results of evaluation of the mixer performance are interpreted in the terms of a Poisson statistics and chi-squared distribution. The value of probability by Poisson ( $p$ ) was chosen as criteria for evaluation of homogeneity. Treating a series of counts as a Poisson distribution, the mix is judged complete if $p>5 \%$ and judged incomplete if $p<1 \%$. The mix is judged "probably incomplete" (marginal) if the probability value is in the range of $1 \%<p<5 \%$.
\end{abstract}

Key words: feed certification, ferromagnetic microtracers, Poisson distribution, chi-squared.

\section{Introduction}

The signing of the Agreement on the Association of Ukraine with the EU allowed domestic producers of agricultural products to enter the promising European market. As it is known, this market is characterized by a high level of competition, and in order to occupy a worthy place in the European market a high level of quality and safety of the products is necessary. One of the certification systems that ensure the production of products whish are corresponding the European quality and safety standards is the GMP+ system. 
GMP+ (Good Manufacturing Practice) certification is a quality control system which is designed to ensure feed safety and provide a guarantee to the consumer regarding the production, processing, trade, storage and transportation of feed ingredients and animal feeds $[1,2]$.

The GMP+ Feed Certification system is based on two modules:

1) The main module associated with ensuring the safety of feed in all parts of the chain of production and supply of feed (GMP + FSA- Feed Safety Assurance module).

2) GMP+ FRA module (Feed Responsibility Assurance), which includes control over the use of prohibited ingredients, technologies and assessment of the impact of production processes on the state of the environment, animal and human health.

The documentation for the GMP+ certification system consists of four parts: A, B, C and D where the most important is part $\mathrm{B}$.

Part A is a set of documents consisting of 5 standards, which describe the general requirements for participation in the GMP+ Feed Certification scheme.

Part B includes normative documents (documents of group B), and also annexes (documents of the BA group), notes for European countries (documents of the $\mathrm{BCN}$ group). $\mathrm{GMP}+\mathrm{B} 1-\mathrm{B} 10$ standards relate to the area of production, trade, transportation, storage, cultivation and laboratory testing of animal feeds and feeds components, taking into account pet food.

Part $\mathrm{C}$ contains documents describing the requirements for the GMP+ certification scheme.

Part D includes documents that are guidelines aimed at helping companies implement GMP+ requirements.

The main standards of group B consist of 4 parts (all versions dated 01.07.2018):

1. Part of GMP+B1: a brief description of all stages, the full description of which is given in the next three parts;

2. Part of GMP+B2: a description of all stages of production;

3. Part of GMP+ B3: description of the stages of trade and storage;

4. Part of GMP+ B4: description of the stages of chartering and transportation.

The method for assessing the quality of feed mixing is presented in the GMP+ BA2 standard. Requirements for GMP+ certification are quite strict for all elements of production and, especially, for quality of feed mixing. The feed manufacturer who decided to undergo the certification procedure must check his equipment on the quality of mixing.

The process of mixing is the most important stage in the production of high-efficiency mixed-feed products. Mixing of loose granular materials is a very complex process, where the mixing components are distributed random chaotic movement of particles. In this case, some parameters of the mixing process depend on the technical features and parameters of the mixer, and other parameters are determined by the properties of the mixture components themselves [3].
The multifaceted nature and complexity of this process and its relationship with other technological processes stipulate the fact that the mixing process will be studied and improved for many years [4, 5]. The mixing process is carried out in various mixers, differing in type, mixer shape, process parameters, etc. The purpose of the process of feeds mixing is obtaining of uniform feed mixture in a minimum period of time in order to maximize the efficiency of the process. Inadequate mixing of feeds ingredients can lead to an increased concentration of toxic components in the mixture, as well as minerals and vitamins in some feed particles or deficiency of these components in other particles. However, there is a danger that excessive mixing can lead to the segregation of ingredients due to the formation of a static charge which is inherent factor of processes of sifting and mixing of the feeds [6].

One of the first analytical reports demonstrating the effect of poor quality mixing of feeds on animal productivity was prepared by Mc. Coy and others [7]. The researchers concluded that depending on the mixing quality analysis method used for the achieving of the maximum performance of broilers, a variation coefficient may be admitted up to $20 \%$, that is twice higher of permissible the current recommendations for the American industry [8].

In recent years, the requirements for homogeneity of mixed fodders have grown in connection with the complication of their formulation, which contains an increasing number of components. It does not really matter if the ingredients fall into the feed directly in the mixer or they are added to the feed within premix.

\section{Materials and methods of analysis}

To control the quality of feeds mixing in the workplace, homogeneity tests are applied using various indicators or tracers, for example, fluorescent food colorings [9]. As tracers, modern techniques involve the use of substances such as chlorides, phosphorus, calcium, manganese, cobalt compounds, and also vitamins, amino acids, and medicines. At the same time, the definition of tracers in feeds such as vitamins or medicinal substances requires the availability of expensive equipment [10].

The American company Micro-Tracers Inc. (San-Francisco, Calif.) [11] is the only manufacturer of ferromagnetic microtracers currently available and has numerous patents on their use in such areas of agricultural production as product quality assessment, labeling of feed components, control for crosscontamination and assessment of the efficiency of the mixers [12-16].

Ferromagnetic tracers variety [11] are particles of iron or stainless steel on the surface of which, the food colorants of various colors are adsorbed. The most common tracers are Microtracers F, which contain about 25,000 iron particles with sizes from 150 to 300 microns. These tracers are used widely in the feed industry to ensure the quality of feeds mixing for animals and poultry during the last 20-30 years. Additional areas of application of these tracers include the marking of vitamins, mineral supplements or medicaments that are 
added to premixes, which allows them to be found in finished feeds. In quantitative analysis tracers can be used not only to determine the effectiveness of mixing but also to assess the adequacy of periodic "cleaning" of mixers and other equipment in the production of feeds.

Currently, tracers are used by companies in many countries, for example, for testing static mixers [17], to determine the presence of hazardous impurities in feeds, such as, coumarin derivatives - ochratoxins which belong to the mycotoxin group, in particular ochratoxin A [18], at constructing of professional testing programs in accordance with standard ISO/IEC 17043 "Conformity assessment. General requirements for the verification of qualifications" [19].

Considering the possibilities of using ferromagnetic microtracers for estimating the quality of mixing, a number of publications [20-24] should be singled out, in which the approach to estimating the homogeneity of the mixture which is based on the use of the Poisson distribution in combination with the Pearson Chi-squared test is substantiated. Although the statistical theory underlying this approach is unquestionable, in our opinion, it would be useful to observe some of the practical aspects associated with the use of ferromagnetic microtracers to determine the homogeneity degree of feed mixtures.

It should be noted that the GMP+ standard distinguishes between direct and indirect methods of estimating the quality of mixing. The first one is based on the principle of particles accounting and when it is used the calculated value of the coefficient of variation can give incorrect results, starting with large values of probability on Poisson. Indirect methods for measuring homogeneity are based on the determination of the concentration of matter. The use of these methods leads to results that are interpreted as a random distribution, i.e. homogeneity is determined by the coefficient of variation in fact. Requirements for homogeneity of mixed fodders in accordance with international GMP+ standards are presented in Tables 1 and 2 (see [25]).

In our researches (see, for example, [26, 27]) ferromagnetic microtracers were introduced into the mixing equipment as one of the micro additives with the recommended dosage of $50 \mathrm{~g}$ per ton of mixed feed. Then, with the help of the rotary detector [11], the particles of the microtracers were separated from the selected mixed feed samples and their number was counted.

In order to process the data which are necessary for the statistical evaluation of the mixing quality of
Table 1 - Requirements for homogeneity of mixed feeds in determining homogeneity using direct methods

\begin{tabular}{||l||l|}
\hline \hline Probability $p$ & \multicolumn{1}{|c|}{ Estimation } \\
\hline \hline$p \leq 1 \%$ & Unsatisfactory mixing \\
\hline \hline \multirow{3}{*}{$1 \%<p<5 \%$} & $\begin{array}{l}\text { Intermediate mixing, which can be } \\
\text { considered as incomplete mixing in } \\
\text { the case when the operator made any } \\
\text { mistake in his actions. It is } \\
\text { recommended to repeat the test }\end{array}$ \\
\hline \hline$p \geq 5 \%$ & Complete mixing \\
\hline
\end{tabular}

Table 2 - Feed uniformity requirements for homogeneity determination by indirect methods

\begin{tabular}{||c||c|}
\hline \hline Variation coefficient, CV & Estimation \\
\hline \hline $\mathrm{CV} \leq 8 \%$ & Complete mixing \\
\hline \hline $8 \%<\mathrm{CV}<12 \%$ & Satisfactory mixing \\
\hline \hline $\mathrm{CV} \geq 12 \%$ & Unsatisfactory mixing \\
\hline
\end{tabular}

multicomponent feeds that is based on the estimation of the distribution of added particles - microtracers, we used the requirements of one of the annexes to the standards of Part B - GMP+ BA2 - Control of residues.

\section{Results and discussion}

Table 3 presents the results of checking the quality of feed mixing with using microtracers which are based on this standard. The following statistics were used for the assessment:

- the average number of particles, $m$;

- standard deviation for the number of particles,

$S$

- the distribution of $\chi^{2}$ (chi-squared);

- probability of particles in \%, as an indicator of homogeneity, $p$.

To calculate the $\chi^{2}$ value, the bellowing formula was used:

$$
\chi^{2}=\frac{\sum_{i=1}^{5} d_{n}^{2}}{m}=\frac{52}{50,4}=1,02,
$$

where: $d_{n}^{2}-$ is the squared of the difference $\left(x_{i}-m\right)$.

In the method $p_{1}$ the number of degrees of freedom was determined by the formula: $r=n-1$, where: $r$-is the number of degrees of freedom, $n-$ is the number of samples taken (sample size).

Table 3 - Results of food quality control with microtracers

\begin{tabular}{|c|c|c|c|c|c|c|c|c|c|c|c|}
\hline \multirow[t]{2}{*}{ № } & \multicolumn{5}{|c|}{ Number of particles in the test samples, $x_{i}$} & \multirow[t]{2}{*}{ 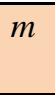 } & \multirow[t]{2}{*}{$p_{1}(\%)$} & \multirow[t]{2}{*}{$p_{2}(\%)$} & \multirow[t]{2}{*}{$\mathrm{S}$} & \multirow[t]{2}{*}{$\overline{\mathrm{CV}(\%)}$} & \multirow[t]{2}{*}{$\chi^{2}$} \\
\hline & 1 & 2 & 3 & 4 & $\overline{5}$ & & & & & & \\
\hline 1 & 47 & 53 & 47 & 55 & 50 & 50 & 90,74 & 79,74 & 3,58 & 7,10 & 1,02 \\
\hline 2 & 47 & 53 & 45 & 65 & 50 & 52 & 31,18 & 18,95 & 7,87 & 15,14 & 4,77 \\
\hline 3 & 43 & 57 & 70 & 35 & 61 & 53 & 0,49 & 0,19 & 14,08 & 26,46 & 14,90 \\
\hline 4 & 43 & 57 & 70 & 45 & 61 & 55 & 5,59 & 2,65 & 11,28 & 20,43 & 9,22 \\
\hline 5 & 43 & 57 & 70 & 38 & 61 & 53 & 1,21 & 0,50 & 13,14 & 24,43 & 12,84 \\
\hline
\end{tabular}

$* p_{1}$ и $p_{2}-$ represent two different methods of estimating the number of degrees of freedom $(r)$ :

$r=n-a$, where $n-$ is the number of samples taken (sample size); $a=1\left(p_{1}\right)$ and $2\left(p_{2}\right)$. 
In this case, according to the $\mathrm{GMP}+\mathrm{BA} 2$ standard table at $\chi^{2}=1,02$ and $r=5-1=4$, the calculated probability $p$ is $90.74 \%$.

In the method $p_{2}$, the formula [28] was used: $r=$ $n-2$. In this case, according to the GMP+ BA2 standard, the calculated probability $p$ is $79.74 \%$ $\left(p\left(\chi^{2}=1,02 ; r=3\right)=79,74 \%\right)$.

Although the difference in the probability values in the case of different methods of estimating, depending on number of degrees of freedom looks significant and in fact it is not critical. This conclusion follows from the fact that in all cases when $\mathrm{p}>5 \%$, the mixing is considered complete (GMP+ BA2 standard).

From the results of the studies shown in Table 3, which are based on the statistical data of the standard and the data of the microtracers producer, the following conclusions can be made about the quality of mixing:

1. For high probability values with respect to the Poisson distribution ( $p>18 \%$ ), both calculation methods show complete mixing, Table. 3 N 1 ( $p=90.74 \%$ and $79.74 \%)$ or Table. 3 N 2 ( $p=31.18 \%$ and $18.95 \%)$;

2 . For small values of the probability relative to the Poisson distribution, both methods of calculation show unsatisfactory mixing, Table. 3 N 3 ( $p=0.49 \%$ and $0.19 \%$ );

3. For probability values relative to the Poisson distribution, which are close to critical values, Table. $3 \mathrm{~N}$ $4(p=5.59 \%$ and $2.65 \%)$ or N $5(p=1.21 \%$ and $0.50 \%)$, there are significant differences in the results of using both methods. In particular, in the case of $\mathrm{N} 4$, using the same initial data, the results of the statistical calculation according to the standard show the value $p=5.59 \%$ (i.e., complete mixing), and the calculation from the manufacturer of the microtracers shows a $p$ value of $2.65 \%$ (that is, intermediate mixing). In the case of $\mathrm{N} 5$, a similar estimate which is based on the results of the statistical calculation according to the standard shows the value of $p=1.21 \%$ (i.e., intermediate mixing), and the calculation according to the microtracers manufacturer shows a value of $p=0.5 \%$ (i.e., an unsatisfactory mixing).

If the test results show incomplete mixing, the GMP+ user must: 1) report possible causes; 2) carry out corrective actions; 3 ) perform a new test to verify that the measures taken lead to complete mixing.

\section{Conclusions}

1. This article discusses the advisability of using ferromagnetic microtracers to quantify the quality of mixing of feed mixtures. The experimental data processing technique, which is included in the GMP+ BA2 standard, is based on the application of Poisson statistics and the calculation of the values of the Pearson criterion chi-squared.

2. It is shown that the use of different methods of estimating the number of degrees of freedom, in most cases, does not affect the conclusion about the completeness of mixing with the probability estimate using the Poisson distribution.

\section{REFERENCES}

1. Velichko V. O. HASSP - sistema koriguyuchih dij zabezpechennya yakosti ta bezpechnosti kormiv, kormovih dobavok, premiksiv i kormovoï sirovini / V. O. Velichko, L. I. Flyak, A. V. Grimak, I. R. Urban // Naukovo-tekhnichnij byuleten' Institutu biologiï tvarin i Derzhavnogo naukovo-doslidnogo kontrol'nogo institutu vetpreparativ ta kormovih dobavok. 2013. - Vip. 14. - № 3-4. - S. 346-351.

2. Beskups'ka O.V. Vprovadzhennya sertifikatu GMP+ na ukrä̈n'kih pidpriєmstvah u konteksti integraciï do $C S / O . V$. Beskups'ka // Molodij vchenij». - 2015. - № 9(24). - C. 38-41.

3. Klimenko A. Kachestvo smeshivaniya kormov i produktivnost' zhivotnyh /A. Klimenko, A. Yaponcev // Kombikorma. 2015. - № 6. - S.50-54.

4. Makarinskaya A.V. Teoreticheskie i prakticheskie osnovy ocenki odnorodnosti kombinirovannyh smesej /A.V. Makarinskaya // Naukovij visnik Poltavs'kogo universitetu ekonomiki i torgivli. - 2016. - № 1(78) - S.68-76.

5. Egorov B.V. Harakteristika smesitelej dlya proizvodstva premiksov i kombikormov /B.V. Egorov, A.V. Makarinskaya, T.G. Stoyanova, N.V. Gonca // Hranenie i pererabotka zerna. - 2008. - № 2. - S.43-46.

6. Sahno T.V. Izuchenie segregacii ferromagnitnyh mikrotrejserov ot premiksov: rezul'taty testirovaniya $v$ model'nyh usloviyah $i$ usloviyah transportirovki $i$ hraneniya /T.V. Sahno, I.V. Korotkova, N.N. Barashkov // Zernovi produkti $i$ kombikormi. - 2017. - V. 17. - N2 . - P.28-33.

7. McCoy R. A. Effect of Mixing Uniformity on Broiler Chick Performance / R.A.McCoy, K.C. Behnke, J.D. Hancock, R.R. Mcellhiney // Poultry Science. - 1994. - V.73 (3). - P.443-451.

8. Herrman T. and Behnke K. Feed Manufacturing - Testing mixer performance. - 1994. Bul. MF-1172 Revised, Kansas St. University Cooperative Extension Service, Manhattan, KS.

9. Matuszek D. The use of the fluorescence phenomenon to evaluate the content of feed ingredients / D. Matuszek // Journal of Research and Applications in Agricultural Engineering. - 2017. - V. 62(2). - P.72-75.

10. Rochaa A.G. Comparison of different indicators for the evaluation of feed mixing efficiency / A.G. Rochaa, R.N. Montanhinic, P. Dilkin, C.D. Tamiosso, C.A. Mallmann// Animal Feed Science and Technology. - 2015. - V. 209. - P. $249-256$.

11. www.microtracers.com

12. Eisenberg S. Iron-based tracers / S. Eisenberg US Pat.3, 469, 990, 1969.

13. Eisenberg S. Microingredient containing tracer/S. Eisenberg US Pat.4, 654, 165, 1987.

14. Eisenberg S. Protected iron tracer composition and method of making /S. Eisenberg US Pat. 17, 188, 408, 1980.

15. Eisenberg S. Tracer-containing composition/S. Eisenberg US Pat.4, 152, 271, 1979.

16. Eisenberg S. Tracers /S. Eisenberg US Pat.4, 029, 820, 1977.

17. Pezo L. The joint mixing action of the static pre-mixer and the rotating drum mixer - Discrete element method approach $/$ L. Pezo, M. Pezo, A. Jovanović, R. Čolović, Đ. Vukmirović, V. Banjac, O. Đuragić // Advanced Powder Technology. 2018. - V. 29(7). - P. 1734-1741. 
18. Evaluation Report proficiency test DLA 23/2016 Contaminated Food: Ochratoxin A in Licorice Powder Dienstleistung Lebensmittel Analytik GbR Waldemar-Bonsels-Weg 17022926 Ahrensburg, Germany proficiency-testing@dla-lvu.de www.dla-lvu.de Coordinator: Dr. G. Wichmann

19. April 2018 DLA 16/2017 - ALM Verification: Peanut Evaluation Report proficiency test DLA 16/2017 ALM Verification: Peanut in Cookie-Matrix 5 Samples containing roasted Peanuts (levels: 0,50 / 2,5 / 5,0 / 12,5 / 25 mg/kg)

20. Eisenberg D.A. Mix with Confidence / D.A. Eisenberg // International Milling Flour\&Feed, June 1994. - P.31-33.

21. Eisenberg D. Microtracers TM $F$ and their uses in assuring the quality of mixed formula feeds / D. Eisenberg // Advances in Feed Technology. - 1992. - V.7. - P.78-85.

22. Eisenberg S. Markers in Mixing Testing: Closer to Perfection /S. Eisenberg, D. Eisenberg // Feed Management. - 1992. 43. - P.8-11.

23. Eisenberg S. and Eisenberg D. "Particle Size and Mixing Problems for Aquatic Feeds", Feed Manufacturing, Technology IV, AFIA, 1994

24. Djuragic O. Evaluation of homogeneity in feed by method of microtracers / O. Djuragic, J. Levic, S. Srednovic, L. Levic // Archiva Zootechnica. - 2009. - V.12 (4). - P. 85-91.

25. GMP+ Feed Certification scheme Module: Feed Safety Assurance GMP+BA2 Control of residues Version EN: 1 July 2018.

26. Barashkov N.N. Ferromagnitnye mikrotrejsery, kak indikatory kachestva odnorodnosti kombikormov dlya zhivotnovodstva $i$ pticevodstva /N.N. Barashkov, P.V. Pisarenko, V.E. Krikunova, T.V. Sahno, O.A. Krikunov// Zernovi produkti $i$ kombikormi. - 2016. - V. 63. - N 13. - R.34-40.

27. Pisarenko P.V. Primenenie ferromagnitnyx mikrotrejserov kak indikatorov kachestva odnorodnosti kombikormov $v$ sel'skom hozyajstve / P.V. Pisarenko, V.E. Krikunova, T.V. Sahno, O.A. Krikunov, N.N. Barashkov// Vestnik Kurganskoj GSHA. - 2016. - T. - № 4. - S.-50-54.

28. Fisher R. A. On the Interpretation of $\chi 2$ from Contingency Tables and the Calculation of P/R.A. Fisher //Journal of the Royal Statistical Society. - 1922. - V. 85. - N 1. - P. 87-94.

Т.В. САХНО, д-р хим. наук, профессор, Полтавский университет экономики и торговли,

П. В. ПИСАРЕНКО, д-р с-г. наук, профессор, И.В. КОРОТКОВА, канд. хим. наук, доцент, Полтавская государственная аграрная академия,

А.Н. ОМЕЛЯН, канд. физ-мат. наук, доцент,

Полтавский национальный технический университет им. Ю.Кондратюка

Н.Н. БАРАШКОВ, д-р хим. наук, профессор, Micro-Tracers Inc., (Сан-Франциско, США)

ПРИМЕНЕНИЕ СТАТИСТИЧЕСКИХ МЕТОДОВ УПРАВЛЕНИЯ

КАЧЕСТВОМ ПО СТАНДАРТАМ GМР+ С ИСПОЛЬЗОВАНИЕМ ФЕРРОМАГНИТНЫХ МИКРОТРЕЙСЕРОВ

\section{Аннотация}

Рассмотрена и проанализирована схема сертификации кормов GMP+ FSA, которая была разработана в 1992 году голландской кормовой промышленностью в ответ на различные инциденты, связанные с загрязнением кормовой продукиии. В настоящее время эта международная схема управляется организацией «GMP+ International» в сотрудничестве с заинтересованными сторонами ряда европейских стран. Одним из наиболее важных и ответственных шагов в прочессе производства кормов является смешивание - создание полностью однородной смеси. В данной работе проведена статистическая оиенки качества смешивания многокомпонентных кормов с использованием распределения добавленных частиц-микротрейсеров. Процедура тестирования однородности кормов и премиксов с использованием микротрейсеров представлена в стандарте GMP+BA2 «Контроль остатков». Ферромагнитная разновидность трейсеров, выпускаемых американской компанией Micro-Tracers, Inс (Сан-Францฺиско, Калифорния), представляет собой частицы железа или нержавеющей стали, на поверхности которых адсорбированы пищевые красители различных изветов. Наиболее распространенными микротрейсерами являются Microtracers F, которые содержат около 25000 частии железа с размерами от 150 до 300 мкм. Эти микротрейсеры используются в кормовой промышленности для обеспечения качества смешивания кормов для животных и птицы в течение последних 20-30 лет. Дополнительные области применения микротрейсеров включают маркировку витаминов, минеральных добавок или лекарственных препаратов, входящих в состав премиксов, что позволяет обнаруживать эти компоненты в готовых кормах. При количественном анализе микротрейсеры могут использоваться не только для документирования эффективности смешивания, но и для оченки адекватности периодчческой «очистки» смесителей и другого оборудования для производства кормов.

В данной работе аналитические результаты оценки производительности смесителя интерпретируются в терминах статистики Пуассона и распределения хи-квадрат. В качестве критерия оченки однородности была выбрана величина вероятности по Пуассону (р). Рассматривая серию отсчетов, как распределение Пуассона, смесь оценивали как полностью однородную, если $p>5 \%$, и неоднородную при $p<1 \%$. Если величина вероятности находится в диапазоне $1 \%<p<5 \%$, то смесь оценивали как «вероятно неоднородную» (маргинальную).

Ключевые слова: сертификации кормов, ферромагнитные микротрейсеры, распределение Пуассона, хи-квадрат. 


\section{ЛИТЕРАТУРА}

1. Величко В. О. ХАССП - система коригуючих дій забезпечення якості та безпечності кормів, кормових добавок, преміксів і кормової сировини / В. О. Величко, Л. І. Фляк, А. В. Гримак, І. Р. Урбан // Науково-технічний бюлетень Інституту біології тварин і Державного науково-дослідного контрольного інституту ветпрепаратів та кормових добавок. - 2013. - Bun. 14. - № 3-4. - C. 346-351.

2. Бескупська О.В. Впровадження сертифікату GMP+ на українських підприємствах у контексті інтеграиії до ЄC /О.В. Бескупська // Молодий вчений». - 2015. - № 9(24). - С. 38-41.

3. Клименко А. Качество смешивания кормов и продуктивность животных /А. Клименко, А. Японщев // Комбикорма. - 2015. - № 6. - C.50-54.

4. Макаринская А.В. Теоретические и практические основы оченки однородности комбинированных смесей /A.B. Макаринская // Науковий вісник Полтавського університету економіки і торгівлі. - 2016. - № 1(78) - C.68-76.

5. Егоров Б.В. Характеристика смесителей для производства премиксов и комбикормов /Б.В. Егоров, А.В. Макаринская, Т.Г. Стоянова, Н.В. Гониа // Хранение и переработка зерна. - 2008. - № 2. - С.43-46.

6. Сахно Т.В. Изучение сегрегащии ферромагнитных микротрейсеров от премиксов: результаты тестирования в модельных условиях и условиях транспортировки и хранения /Т.В. Сахно, И.В. Короткова, Н.Н. Барашков // Зернові продукти і комбікорми. - 2017. - V. 17. - N2 - - P.28-33.

7. McCoy R. A. Effect of Mixing Uniformity on Broiler Chick Performance / R.A.McCoy, K.C. Behnke, J.D. Hancock, R.R. Mcellhiney // Poultry Science. - 1994. - V.73 (3). - P.443-451.

8. Herrman T. and Behnke K. Feed Manufacturing - Testing mixer performance. - 1994. Bul. MF-1172 Revised, Kansas St. University Cooperative Extension Service, Manhattan, KS.

9. Matuszek D. The use of the fluorescence phenomenon to evaluate the content of feed ingredients / D.Matuszek // Journal of Research and Applications in Agricultural Engineering. - 2017. - V. 62(2). - P.72-75.

10. Rochaa A.G. Comparison of different indicators for the evaluation of feed mixing efficiency / A.G. Rochaa, R.N. Montanhinic, P. Dilkin, C.D. Tamiosso, C.A. Mallmann// Animal Feed Science and Technology. - 2015. - V. 209. - P. 249-256.

11. www.microtracers.com

12. Eisenberg S. Iron-based tracers / S. Eisenberg US Pat.3, 469, 990, 1969.

13. Eisenberg S. Microingredient containing tracer/S. Eisenberg US Pat.4, 654, 165, 1987.

14. Eisenberg S. Protected iron tracer composition and method of making / S. Eisenberg US Pat. 17, 188, 408, 1980.

15. Eisenberg S. Tracer-containing composition/S. Eisenberg US Pat.4, 152, 271, 1979.

16. Eisenberg S. Tracers /S. Eisenberg US Pat.4, 029, 820, 1977.

17. Pezo L. The joint mixing action of the static pre-mixer and the rotating drum mixer - Discrete element method approach / L. Pezo, M. Pezo, A. Jovanović, R. Čolović, D. Vukmirović, V. Banjac, O. Đuragić // Advanced Powder Technology. 2018. - V. 29(7). - P. 1734-1741.

18. Evaluation Report proficiency test DLA 23/2016 Contaminated Food: Ochratoxin A in Licorice Powder Dienstleistung Lebensmittel Analytik GbR Waldemar-Bonsels-Weg 17022926 Ahrensburg, Germany proficiency-testing@dla-lvu.de www.dla-lvu.de Coordinator: Dr. G. Wichmann

19. April 2018 DLA 16/2017 - ALM Verification: Peanut Evaluation Report proficiency test DLA 16/2017 ALM Verification: Peanut in Cookie-Matrix 5 Samples containing roasted Peanuts (levels: 0,50 / 2,5 / 5,0 / 12,5 / 25 mg/kg)

20. Eisenberg D.A. Mix with Confidence / D.A. Eisenberg // International Milling Flour\&Feed, June 1994. - P.31-33.

21. Eisenberg D. Microtracers TM F and their uses in assuring the quality of mixed formula feeds / D. Eisenberg // Advances in Feed Technology. - 1992. - V.7. - P.78-85.

22. Eisenberg S. Markers in Mixing Testing: Closer to Perfection /S. Eisenberg, D. Eisenberg // Feed Management. - 1992. 43. - P.8-11.

23. Eisenberg S. and Eisenberg D. "Particle Size and Mixing Problems for Aquatic Feeds", Feed Manufacturing, Technology IV, AFIA, 1994

24. Djuragic O. Evaluation of homogeneity in feed by method of microtracers / O. Djuragic, J. Levic, S. Srednovic, L. Levic // Archiva Zootechnica. - 2009. - V.12 (4). - P. 85-91.

25. GMP+ Feed Certification scheme Module: Feed Safety Assurance GMP+BA2 Control of residues Version EN: 1 July 2018.

26. Барашков Н.Н. Ферромагнитные микротрейсеры, как индикаторы качества однородности комбикормов для животноводства и птицеводства /Н.Н. Барашков, П.В. Писаренко, В.Е. Крикунова, Т.В. Сахно, О.А. Крикунов// Зернові продукти і комбікорми. - 2016. - V. 63. - N 13. - P.34-40.

27. Писаренко П.В. Применение ферромагнитных микротрейсеров как индикаторов качества однородности комбикормов в сельском хозяйстве / П.В. Писаренко, В.Е. Крикунова, Т.В. Сахно, О.А. Крикунов, Н.Н. Барашков// Вестник Курганской ГСХА. - 2016. - Т. - № 4. - C.-50-54.

28. Fisher R. A. On the Interpretation of $\chi 2$ from Contingency Tables and the Calculation of $P / R$.A. Fisher $/ / J o u r n a l$ of the Royal Statistical Society. - 1922. - V. 85. - N 1. - P. 87-94.



